\title{
Biologi Kepiting Bakau Scylla Serrata, Forsskål, 1775 (Malacostraca : Portunidae) Berdasarkan Pola Pertumbuhan dan Parameter Pertumbuhan pada Bulan Oktober, November, Desember di Perairan Ketapang, Pemalang
}

\author{
Naily Fitriyani*, Chrisna Adhi Suryono, Ria Azizah Tri Nuraini \\ Departemen IImu Kelautan, Fakultas Perikanan dan IImu Kelautan, Universitas Diponegoro \\ JI. Prof.H.Soedarto S.H, Tembalang,Semarang, Jawa Tengah 50275 Indonesia \\ *Corresponding author, e-mail : nailyfitriyani@yahoo.com
}

\begin{abstract}
ABSTRAK: Desa Ketapang, Pemalang merupakan salah satu sumber potensi tangkapan kepiting yang memiliki nilai ekonomis tinggi. Tingginya permintaan pasar baik lokal maupun global menyebabkan naiknya penangkapan kepiting tanpa adanya restocking sepanjang tahun. Hal ini mengkhawatirkan kondisinya di alam. Penelitian ini bertujuan untuk memonitoring kepiting bakau (Scylla serrata) di Perairan Desa Ketapang, Pemalang dengan mengetahui distribusi ukuran, pola pertumbuhan dan faktor kondisi, serta nilai parameter pertumbuhan berdasarkan persamaan Von Bertalanff. Penelitian ini dilakukan pada bulan Oktober-Desember 2019 dengan 2 kali pengambilan dalam 1 bulan (fase bulan purnama dan fase bulan baru). Metode pengumpulan data pada penelitian ini menggunakan metode survei. Data tangkapan kepiting bakau diperoleh dari hasil tangkapan nelayan yang ada di pengepul kepiting Desa Ketapang. Pengolahan data dilakukan dengan menggunakan Ms. Excel 2013 dan FISAT II. Distribusi ukuran rata-rata lebar karapas kepiting pada bulan purnama yaitu 40,38 $\pm 7,98 \mathrm{~mm}$, sedangkan pada bulan baru yaitu $39,89 \pm 6,48 \mathrm{~mm}$. Pola pertumbuhan kepiting pada bulan Oktober - Desember 2019 menunjukkan pola pertumbuhan allometrik negative $(b<3)$ dengan nilai faktor kondisi diatas 100 , yang berarti wilayah Perairan Desa Ketapang mempengaruhi pertumbuhan kepiting dari segi sumber makanan. Didapatkan nilai persamaan pertumbuhan pada saat bulan purnama adalah $\mathrm{Lt}=30.8$ $(1-\exp (0.51(t+1.93264)))$, sedangkan pada bulan baru adalah $\mathrm{Lt}=30.5(1-\exp (4.56(t+0.19933)))$.
\end{abstract}

Kata kunci: Scylla serrata; Von bertalanffy; Bulan Purnama; Bulan Baru

\author{
Biology of Mud Crab Scylla serrata, Forsskål, 1775 (Malacostraca: Portunidae) \\ based on Growth Pattern and growth parameters in October, November, December \\ in Ketapang waters, Pemalang
}

\begin{abstract}
Ketapang is one of village in Pemalang which has potential sources of crab catches that have high economic value. The high demand of local and global markets cause an increasing in crab catch without any restocking throughout the year. It is worrying about its condition in nature. The study aims to monitor mangrove crabs (Scylla serrata) in Ketapang waters, Pemalang by knowing the size distribution, pattern growth, condition factor, and the value of growth parameters based on The equation Von Bertalanff. The study has been conducted in October-December 2019 with 2 retrievals in 1 month (Full moon phase and New Moon phase). The method of collecting data on this study uses the survey method. Mangrove Crab capture Data is obtained from the catch of fishermen in the crab-Pinke Ketapang village. Data was analyse used Ms. Excel 2013 And FISAT II software. The average size distribution of crab carapace in the full moon is $40.38 \pm 7.98$ $\mathrm{mm}$, while in the New Moon is $39.89 \pm 6.48 \mathrm{~mm}$. The pattern of crab growth in October December 2019 showed negative allometri growth pattern $(b<3)$ with condition factor value above 100 , which means the water area of Ketapang village affects the growth of crabs in terms of food sources. Acquired value of growth equation during full moon is $L t=30.8$ (1-exp $(0.51$ ( $t+$ 1.93264))), while the new Moon is $L t=30.5(1-\exp (4.56(t+0.19933)))$.
\end{abstract}

Keywords: Scylla serrata; Von bertalanffy; Full moon; New Moon 


\section{PENDAHULUAN}

Pemalang merupakan salah satu daerah di kawasan utara Jawa Tengah yang memiliki potensi cukup baik pada sektor sumberdaya perikanan tangkap. Salah satu komoditas unggulan hasil tangkapan lautnya adalah kepiting. Pada tahun 2004 Kabupaten Pemalang menempati urutan ke-6 dari seluruh kabupaten di Jawa Tengah sebagai sumber penghasil tangkapan perikanan laut Jawa Tengah (Dinas Kelautan dan Perikanan Propinsi Jawa Tengah, 2005). Akan tetapi, seiring dengan permintaan pasar secara global yang meningkat tidak mampu mengimbangi produksi tangkapan. Sedangkan, Menurut Kementrian Kelautan dan Perikanan (2012), Produksi kepiting di Jawa Tengah tahun 2007 - 2010 pada sektor budidaya mengalami penurunan drastis. Kepiting Scylla serrata memiliki potensi sebagai penyangga kehidupan masyarakat bagi nelayan di Desa Ketapang, Pemalang yang berskala kecil karena memiliki nilai ekonomis yang tinggi. Banyak masyarakat yang mengkomsumsi kepiting tersebut karena populasinya lebih banyak dibandingkan kepiting lainnya.

Kepiting dapat ditemukan diseluruh perairan pantai terutama di daerah yang ditumbuhi hutan bakau. Terdapat juga di daerah estuaria dan daerah lepas pantai yang mempunyai subtrat dasar perairan berlumpur (Suryono et al., 2016). Kepiting jenis ini memiliki pasangan kaki terakhir yang berbentuk pipih dan digunakan untuk berenang. Oleh karena itu, biasa disebut swimming crab atau kepiting perenang (Widianingsih et al., 2019). Perairan di dekat kawasan hutan mangrove terdapat jumlah benthos dan serasah yang cukup tinggi sehingga sangat tepat untuk menjadi tempat mencari sumber makanan kepiting (Avianto et al., 2013). Kepiting bakau dalam menjalani kehidupannya dari perairan pantai ke laut, kemudian setelah dewasa berusaha kembali ke perairan pantai, muara sungai, atau hutan bakau untuk berlindung, mencari makanan, atau tumbuh berkembang. Kepiting bakau yang telah siap melakukan perkawinan akan memasuki hutan bakau dan tambak (Farhaby, 2017). Kepiting betina matang pada ukuran lebar karapas antara 80-120 mm sedangkan kepiting jantan matang pada lebar karapas berukuran 90-110 mm, tetapi biasanya pada lebar karapas 140-160 kepiting tidak cukup berhasil bersaing menuju fase pemijahan sebelum dewasa (Tahmid et al., 2015).

Menurut Siringoringo et al. (2017) di Indonesia terdapat peraturan yang mengatur tentang batas penangkapan ukuran jenis lobster, kepiting dan rajungan yaitu pada peraturan Menteri Kelautan Republik Indonesia Nomor 1/PERMEN-KP/2015. Sehingga dibutuhkan informasi tentang ukuran penangkapan pada kepiting bakau (Scylla serrata) agar nelayan didaerah Pemalang mengerti ukuran yang seharusnya ditangkap dan dimanfaatkan. Penangkapan di desa ini dilakukan sepanjang tahun tanpa adanya restocking dan monitoring. Hal ini dapat mengkhawatirkan kondisi jumlahnya di alam. Penelitian ini bertujuan untuk mengetahui distribusi ukuran, pola pertumbuhan dan faktor kondisi kepiting bakau (Scylla serrata) serta nilai parameter pertumbuhan berdasarkan persamaan Von Bertalanff di Perairan Desa Ketapang, Kabupaten Pemalang.

\section{MATERI DAN METODE}

Penelitian ini dilakukan 6 kali selama tiga bulan, yaitu pada Bulan Oktober, November dan Desember 2019 di desa Ketapang Kecamatan Ulujami Kabupaten Pemalang. Penelitian dilaksanakan 2 kali pengambilan data dalam satu bulan, saat pasang laut bertepatan dengan bulan purnama dan bulan baru atau bulan mati pada Tanggal 1 Oktober, 15 Oktober, 30 Oktober, 13 November, 29 November dan 13 Desember 2019. Kepiting bakau Scylla serrata yang digunakan dalam penelitian ini adalah hasil tangkapan nelayan di perairan Desa Ketapang, Pemalang dengan menggunakan alat tangkap bubu. Total Jumlah Kepiting hasil tangkapan yang digunakan pada penelitian ini sebanyak 698 ekor.

Pengukuran panjang kepiting di lakukan dengan mengukur panjang karapas, lebar karapas dan berat total kepiting. Pengukuran panjang dan lebar karapas menggunakan jangka sorong dengan ketelitian $0,1 \mathrm{~mm}$ dan berat total kepiting di ukur menggunakan neraca digital dengan ketelitian 10 gram.

Hasil pengukuran panjang, lebar dan berat karapas kemudian di olah menggunakan Microsoft excel untuk mengetahui pola pertumbuhan kepiting. Model pertumbuhan berbasis 
panjang kepiting bakau di hitung menggunakan rumus yang dikemukaan oleh Von Bertalanffy (Irwani et al., 2019). Nilai L $\infty$ dan K didapatkan dari hasil ELEFAN 1 yang terdapat pada program FISAT II. Nilai t0 dapat menggunakan rumus empiris Pauly.

\section{HASIL DAN PEMBAHASAN}

Hasil pengukuran rata-rata lebar karapas kepiting pada bulan purnama yaitu 40,38 $\pm 7,98$ $\mathrm{mm}$, sedangkan pada bulan baru yaitu 39,89 $\pm 6,48 \mathrm{~mm}$. Hasil Pengukuran rata-rata berat kepiting pada bulan purnama yaitu 196,43 \pm 40,65 gram , sedangkan pada bulan baru yaitu $209,10 \pm 29,20$ gram. Berdasarkan pengamatan didapatkan bahwa hasil tangkapan kepiting pada saat bulan purnama lebih tinggi dari pada saat bulan baru (Gambar. 2). Hal ini sesuai dengan penelitian Avianto et al. (2013) yang mengatakan bahwa pada fase bulan purnama kepiting bakau akan berjalan menuju perairan yang lebih dalam hingga kedalaman 20 meter, sedangkan pada saat bulan baru akan bergerak menuju perairan mangrove, karena kepiting bakau adalah organisme yang bersifat fototaksis negative.Berdasarkan informasi yang didapat dari nelayan setempat, alat tangkap bubu yang digunakan oleh nelayan kepiting di Perairan Desa Ketapang memiliki panjang tali sekitar 5-10 meter, sehingga pendapat Avianto et al. (2013) sesuai dengan kondisi lapangan penelitian. Lebar rata-rata karapas kepiting pada bulan purnama dan bulan baru kurang dari $5 \mathrm{~cm}$. Ukuran tersebut sangat muda dibandingkan penelitian dari Widianingsih et al. (2019), bahwa kepiting yang tertangkap merupakan golongan dari fase muda yang memiliki lebar karapas antara $70-120 \mathrm{~cm}$. Hal ini diduga berkaitan dengan siklus reproduksi kepiting bakau yang memijah pada saat bulan purnama (Avianto et al., 2013). Berawal dari telur yang menetas, kemudian menjadi larva tingkat 1 (zoea 1). Setelah itu kepiting akan berganti kulit dan terbawa arus ke perairan pantai hingga mencapai fase kepiting muda. Proses dari fase zoea 1 menuju fase kepiting muda membutuhkan waktu kurang lebih satu bulan. Kemungkinan kepiting yang tertangkap pada penelitian ini merupakan hasil dari proses pemijahan satu bulan sebelumnya. Namun, hasil tangkapan tersebut belum memenuhi persyaratan pada peraturan Menteri Kelautan Republik Indonesia Nomor 1/PERMEN-KP/2015 yang mengatur tentang batas minimum lebar karapas yang ditangkap adalah lebih dari $15 \mathrm{~cm}$, sehingga diperlukan sosialisasi terhadap nelayan Desa Ketapang, Pemalang.

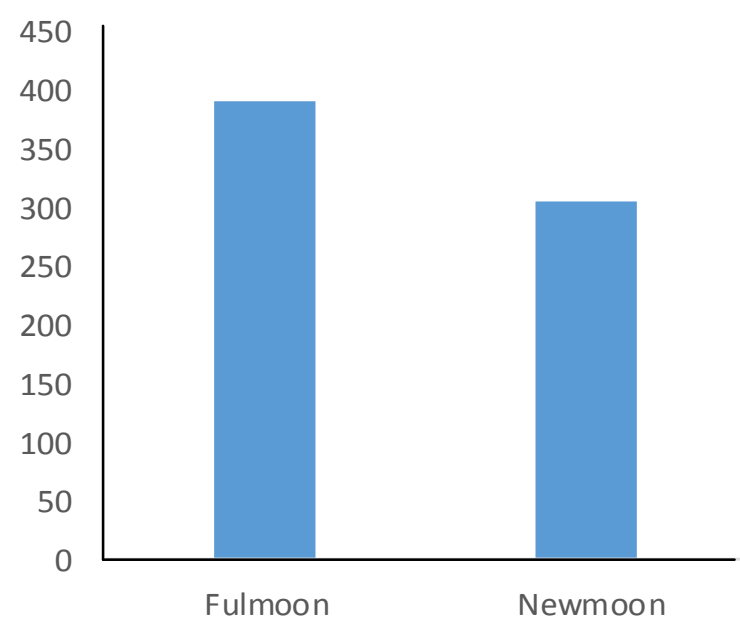

Gambar 1. Hasil Tangkapan Kepiting Bakau (Scylla serrata) pada Bulan Purnama (Full Moon) dan Bulan Baru (New Moon)

Tabel 1. Hasil analisa Regresi Linear Panjang Berat dan Faktor Kondisi

\begin{tabular}{ccccccc}
\hline Jenis Kelamin & $\mathrm{a}$ & $\mathrm{b}$ & $\mathrm{R}^{2}$ & $\mathrm{~W}=\mathrm{aL}^{\mathrm{b}}$ & Faktor Kondisi & Pola Pertumbuhan \\
\hline Full Moon & 6.83 & 1.02 & 0.70 & $6.83 \mathrm{~L}^{1.02}$ & 100.709 & Allometrik Negatif \\
New Moon & 5.69 & 1.08 & 0.56 & $5.69 \mathrm{~L}^{1.08}$ & 100.464 & Allometrik Negatif \\
\hline
\end{tabular}


Berdasarkan hasil analisa hubungan panjang karapas dan berat kepiting (Gambar 3) pada saat bulan purnama dan bulan baru menunjukkan persamaan nilai $b<3$, yang berarti pola pertumbuhan kepiting pada bulan Oktober - Desember adalah pola allometrik negatif. Hasil ini sesuai dengan Penelitian Farhaby (2017) yang mengatakan bahwa hasil nilai $b<3$ di tiga lokasi penelitian baik di Laguna, Muara maupun Tambak di Desa Mojo, Pemalang yang berarti pola pertumbuhannya allometrik negatif. Pertumbuhan kepiting bersifat allometrik negatif berarti bahwa pertambahan panjang karapas lebih cepat dibandingkan berat tubuh kepiting. Faktor kondisi dapat ditentukan dengan analisa panjnang karapas dan berat kepiting melalui rata-rata berat relative (Wr) suatu individu. Pada saat bulan purnama dan bulan penuh kepiting memiliki berat relatif sebesar (Tabel 1). Hasil tersebut menunjukan rata-rata faktor kondisi berada diatas 100. Artinya bahwa perairan Pemalang memiliki cukup persedian makanan dan kepadatan predator yang rendah bagi populasi kepiting. Sesuai dengan penelitian Natsir et al. (2016) mendapatkan nilai berat relatif (Wr) diatas 101.05, maka dapat menunjukkan adanya ketersediaan makanan yang tinggi atau rendahnya kepadatan predator dalam suatu ekosistem.

Berdasarkan Metode non-parametric Scoring of VBGF Fit Using ELEFAN I yang terdapat dalam paket program FISAT II menghasilkan nilai koefisien pertumbuhan (K) dan panjang asimtotik $\left(L_{\infty}^{\infty}\right)$ (Tabel 2). Nilai-nilai pertumbuhan tersebut digunakan untuk mendapatkan persamaan Von Bertalanffy. Hasil persamaan pada saat bulan purnama adalah Lt $=30.8$ (1$\left.\exp ^{(0.51(t+1.93264))}\right)$, sedangkan pada bulan baru adalah $L t=30.5\left(1-\exp ^{(4.56(t+0.19933))}\right)$. Dari persamaan diperoleh kurva pertumbuhan kepiting bakau seperti yang terlihat pada Gambar 6 . Jika dilihat dari kurva parameter pertumbuhan kepiting baik pada saat bulan purnama maupun bulan baru, diawal pertumbuhan kepiting mengalami pertumbuhan yang relatif cepat.

Namun pada hasil kurva parameter bulan purnama (Gambar 6a) dari umur 0-6 tahun pertumbuhannya relatif teratur dan melambat seiring bertambahnya umur sampai mencapai lebar asimptotnya. Sedangkan pada hasil kurva parameter pertumbuhan bulan baru (Gambar $6 \mathrm{~b}$ ) hanya dari umur 0-2 tahun mengalami pertumbuhan yang sangat cepat kemudian langsung stagnan. Hasil tersebut sesuai dengan penelitian Monoarfa et al. (2013) di Kecamatan Kwandang, Gorontalo Utara bahwa pertumbuhan kepiting bakau pada umur satu tahun relatif cepat dan pada saat kepiting mencapai umur dua sampai tiga tahun pertumbuhannya cenderung lambat. pertumbuhan Scylla serrata yang cepat terjadi pada umur muda karena energi yang didapatkan dari makanan sebagian besar digunakan untuk pertumbuhan, sedangkan pada biota tua energy

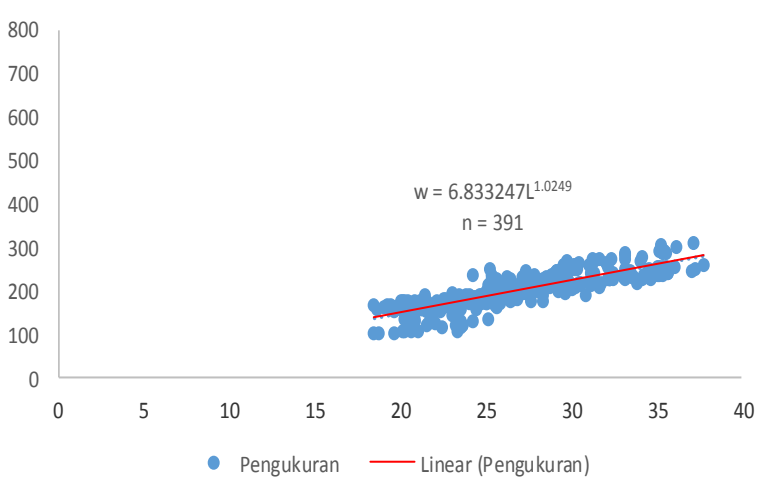

(a)

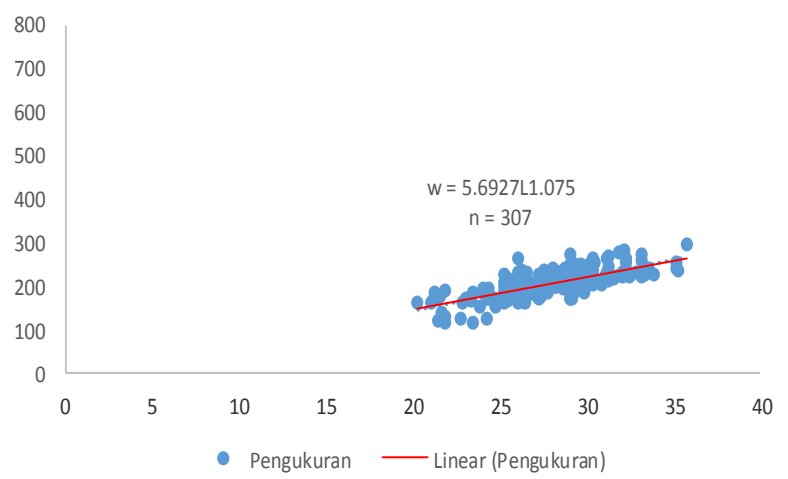

(b)

Gambar 2. Hubungan Panjang Berat pada saat Full Moon (a) dan New Moon (b)

Tabel 2. Nilai Parameter Pertumbuhan kepiting

\begin{tabular}{cccc}
\hline \multirow{2}{*}{ Waktu } & \multicolumn{3}{c}{ Parameter Pertumbuhan } \\
\cline { 2 - 4 } & $\mathrm{L} \infty(\mathrm{mm})$ & $\mathrm{K}$ (per tahun) & t0 \\
\hline Full Moon & 30.8 & 0.51 & -1.93264 \\
New Moon & 30.5 & 2.08 & -0.19933 \\
\hline
\end{tabular}




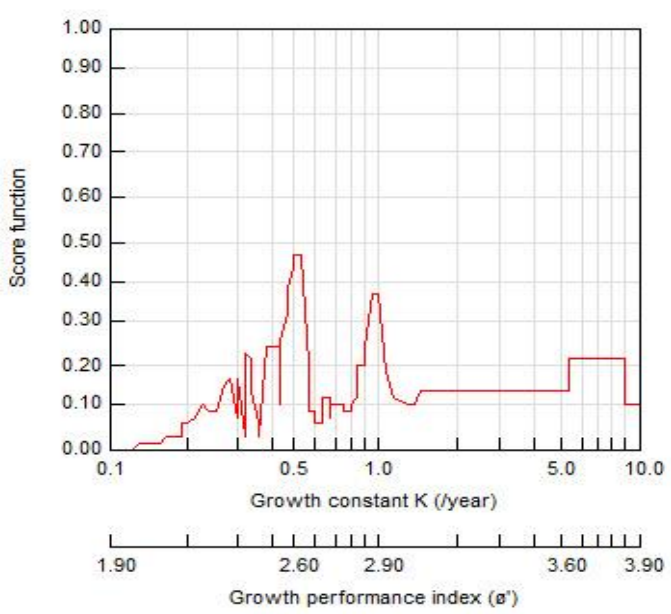

(a)

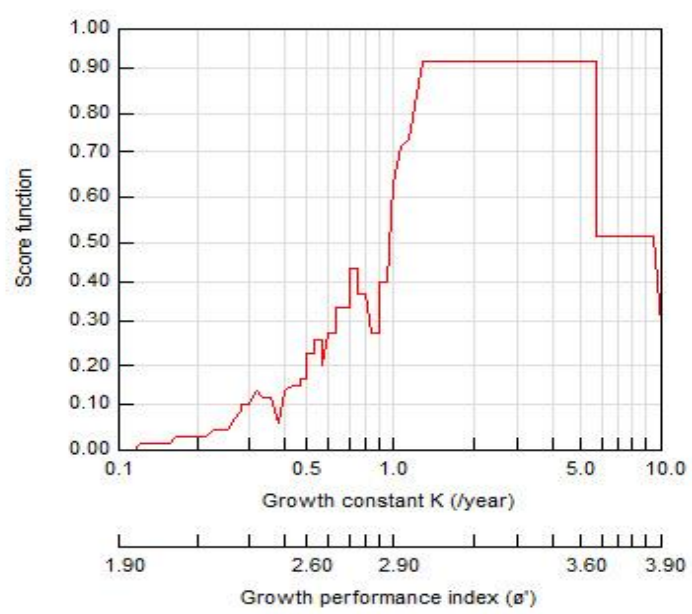

(b)

Gambar 3. Hasil Output K-Scan dari Software FISAT II pada bulan purnama (a) dan pada bulan baru (b)

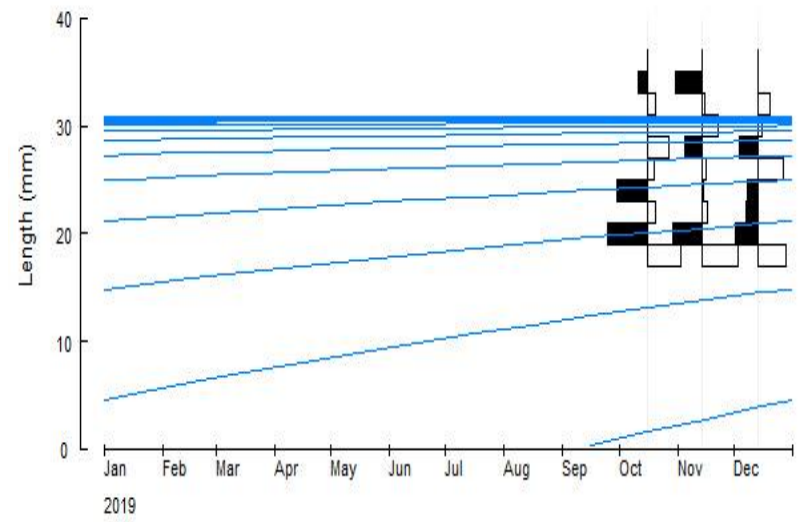

(a)

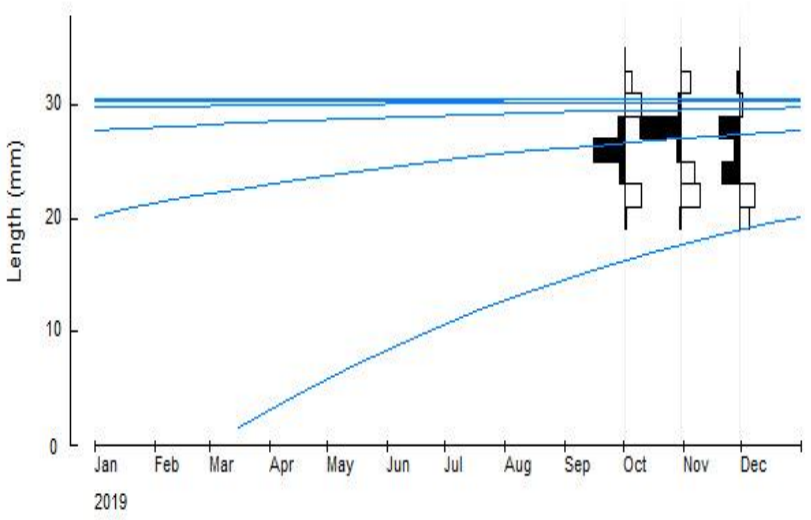

(b)

Gambar 4. Hasil Output Plot VBGF dari Software FISAT II pada bulan purnama (a) dan padabulan baru (b)

yang didapatkan dari makanan digunakan untuk mempertahankan dirinya dan mengganti sel - sel yang rusak. Sumber makanan yang dibutuhkan dipengaruhi oleh kondisi lingkungan. Jika dikaitkan dengan nilai faktor kondisi yang didapatkan pada bulan purnama memiliki nilai faktor kondisi lebih tinggi dari pada saat bulan baru. Sehingga kurva parameter bulan purnama terlihat lebih stabil atau teratur dibanding kurva bulan baru.

Pada fase bulan terjadi perbedaan kekuatan pasang, sehingga mempengaruhi massa air yang membawa nutrien sebagai sumber makanan (Subiyanto et al., 2014), hal tersebut diduga dapat menyebabkan perbedaan kurva parameter pertumbuhan (Gambar 6). Kurva pertumbuhan kepiting digambarkan dari umur 1 tahun samapai 12 tahun dengan rentang masing-masing kelompok umur 1 tahun. Nilai koefisien pertumbuhan $(\mathrm{K})$ kepiting pada bulan purnama maupun bulan baru adalah lebih dari 0.5. Hasil tersebut sesuai dengan penelitian Masiyah (2014) di Perairan Distrik Merauke yang mendapat nilai $\mathrm{K}$ lebih dari 0.5 pertahun menunjukkan bahwa pertumbuhan kepiting tergolong cepat, sehingga semakin besar nilai $\mathrm{K}$ maka semakin cepat pula pertumbuhan untuk mencapai ukuran maksimalnya. Menurut Kembaren et al. (2012) nilai koefisien yang cukup tinggi dengan panjang asimptotik yang lebih rendah merupakan khas mayoritas spesies tropis, kaena berkaitan dengan kondisi lingkungan di perairan tropis yang mempunyai ketersediaan pakan alami yang cukup untuk pertumbuhan kepiting. 


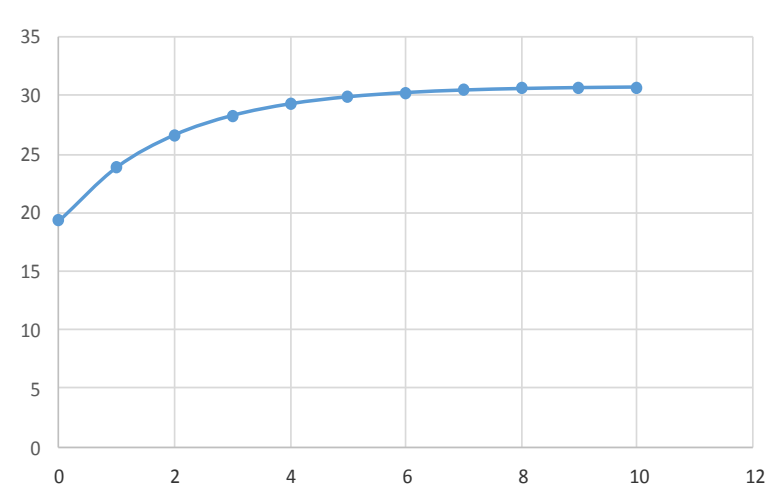

(a)

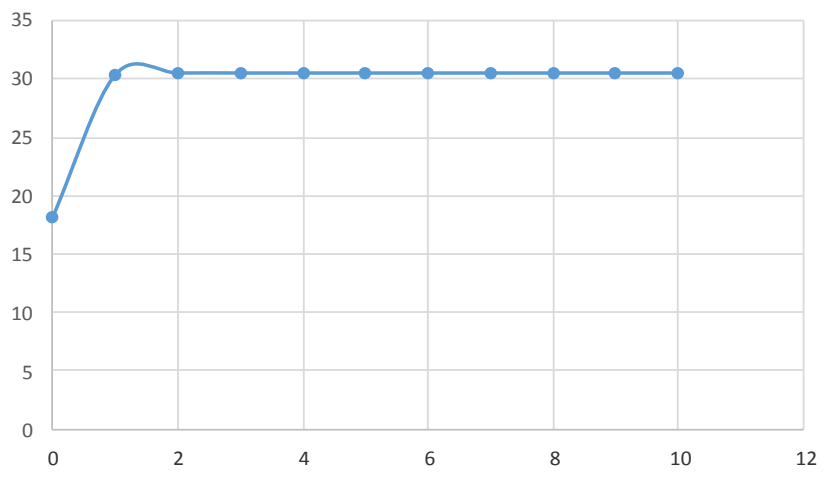

(b)

Gambar 4. Kurva Pertumbuhan kepiting pada bulan purnama (a) dan pada bulan baru (b)

\section{KESIMPULAN}

Berdasarkan hasil penelitian menunjukkan bahwa lebar karapas kepiting pada bulan purnama yaitu 40,38 $\pm 7,98 \mathrm{~mm}$, sedangkan pada bulan baru yaitu 39,89 $\pm 6,48 \mathrm{~mm}$ yang artinya didominasi oleh kepiting dalam fase juvenile. Hubungan antara panjang karapas dan berat kepiting bakau pada penelitian ini adalah pola allometrik negatif $(b<3)$ yang berarti pertumbuhan panjang karapas lebih cepat dari pertumbuhan beratnya. Nilai faktor kondisi yang didapat lebih dari 100, yang artinya bahwa kondisi perairan di Desa Ketapang, Pemalang cukup baik. Pada saat bulan purnama didapatkan panjang asimtotik $\left(L^{\infty}\right) 30.8$ dan koefisien pertumbuhan $(K)$ sebesar 0.51 per tahun. Sedangkan, pada bulan baru didapatkan panjang asimtotik $\left(L^{\infty}\right) 30.5$ dan koefisien pertumbuhan $(\mathrm{K})$ sebesar 20.8 per tahun.

\section{DAFTAR PUSTAKA}

Avianto, I., Sulistiono, S. \& Setyobudiandi, I., 2013. Karakteristik Habitat Dan Potensi Kepiting Bakau (Scylla serrata, S. transquaberica, and S. olivacea) Di Hutan Mangrove Cibako, Sancang, Kabupaten Garut Jawa Barat. Aquasains, 2(1):97-106.

Farhaby, A.M. 2017. Kajian Karakteristik Biometrika Kepiting Bakau (Scylla Sp) di Kabupaten Pemalang, Studi Kasus di Desa Mojo Kecamatan Ulujami. Jurnal Sumberdaya Perairan. 11(1):48-53.

Irwani., Widy, F., Agus, S. \& Diah, P.W. 2019. Laju Ekploitasi Lobster Batu Panulirus penicillatus, Olivier, 1791 (Malacostraca : Palinuridae) di Perairan Laut Yogyakarta. Jurnal Kelautan Tropis. 22(2):197-202.

Kembaren, D.D. Tri, E. \& Suprapto. Biologi dan Parameter Populasi Rajungan (Portunus Pelagicus) Di Perairan Bone dan sekitarnya. Jurnal Penelitian Perikanan Indonesia. 18(4):273281.

Masiyah, S. 2014. Perbedaan Tingkat Pertumbuhan dan Rekruitmen Kepiting Bakau (Scylla Serrata Forsscall, 1775) Pada Distrik Merauke - Kimaam di Ekosistem Mangrove Kabupaten Merauke Propinsi Papua. Jurnal IImiah agribisnis dan Perikanan. 7(1):10-18.

Monoarfa, S., Syamsuddin \& Hamzah, S.N. 2013. Analisis Parameter Dinamika Populasi Kepiting Bakau (Scylla serrata) di Kecamatan Kwandang, Kabuparen Gorontalo Utara. Jurnal IImiah Perikanan dan Kelautan, 1(1):31-36.

Nasir, M., Zainal, A., Muchlisin \& Abdullah, A.M. 2016. Hubungan Panjang Berat dan Faktor Kondisi Ikan Betutu (Oxyeleotris marmorata) di Sungai Ulim Kabupaten Pidie Jaya, Provinsi Aceh, Indonesia. Jurnal Ilmiah Mahasiswa Kelautan dan Perikanan Unsyiah. 1(3): 262-267.

Natania, T., Herliany, N.E. \& Kusuma, A.B. 2017. Struktur Komunitas Kepiting Biola (Uca spp.) di Ekosistem Mangrove Desa Kahyapu Pulau Enggano. Jurnal Enggano 2(1):11-24. 
Santoso, A., Sunaryo \& Ali, D. 2017. Kesadahan Air Media Pemeliharaan dan Pengaruhnya Terhadap Kualitas Produk Kepiting Soka. Jurnal Kelautan Tropis. 20(2):145-153.

Siringoringo, Y.N., Desrita \& Yunasfi. 2017. Kelimpahan dan Pola Pertumbuhan Kepiting Bakau (Scylla serrate) di hutan mangrove Kel. Belawan Sicanang, Kec. Medan Belawan. Provinsi Sumut. Acta Aquatica. 4(1):26-32.

Subiyanto., Wahyu, P.A. \& Max, R.M. 2014. Kelimpahan Zooplankton Krustasea Berdasarkan Fase Bulan di Perairan Pantai Jepara, Kabupaten Jepara. Diponegoro Journal of Maquares. 3(3):188-196.

Suryono, C.A., Irwani \& Rochaddi, B. 2016. Pertambahan Biomasa Kepiting Bakau Scylla serrata pada Daerah Mangrove dan Tidak Bermangrove. Universitas Diponegoro. Semarang. Jurnal Kelautan Tropis. 19(1):76-80.

Tahmid, M., Achmad F \& Yusli W. 2015. Kajian Struktur Ukuran Dan Parametr Populasi Kepiting Bakau (Scylla serrata) di Ekosistem Mangrove Teluk Bintan, Kepulauan Riau. Jurnal Biologi Tropis. 15(2):93-106.

Widianingsih, W., Ria, A.T.N., Retno, H., Sri, R., Ita, R., Cantika, E.A., Hadi, E. \& Robertus, T.M. 2019. Morfometri Dan Pertumbuhan Scylla serrata (Filum: Arthropoda, Famili: Portunidae) Di Desa Panikel, Segara Anakan, Cilacap. Jurnal Kelautan Tropis. 22(1):57-62. 